\title{
Review of Alberto Mingardi's Classical Liberalism and the Industrial Working Class: The Economic Thought of Thomas Hodgskin. New York, NY: Routledge, 2020, 160 pp.
}

\author{
DANIEL LAYMAN \\ Davidson College
}

One of the most exciting recent trends in the history of social and political thought is the attention scholars have begun to pay to non-canonical figures. Thomas Hodgskin, however, has, with a few exceptions (Stack 1998 and Layman 2020, for instance), remained on the sidelines of this expanding field of play. Moreover, to the extent that Hodgskin has received scholarly attention during the last century, it has mostly been to cast him as a fairly minor nineteenth-century socialist (for example, Berlin 2019). In this important new book, Alberto Mingardi sets out both to bring Hodgskin and his accomplishments out of obscurity and to reframe the English journalist, economist, and activist as an important figure in the classical liberal tradition of political economy, stretching from Adam Smith to Friedrich Hayek, and beyond.

In chapter one, we meet Hodgskin, the man-failed naval officer, selftrained economist, journalist, and polemicist. Hodgskin, Mingardi tells us, was born to lower middle-class circumstances in Chatham, Kent, in 1787. After a brief and bitter stint in the Royal Navy that would later inspire his first theoretical work, An Essay on Naval Discipline (1813), he matriculated at the University of Edinburgh as a literature student. He never graduated, but he did form new acquaintances that led to his introduction to Francis Place (1771-1854), an important figure in London's radical working-class intellectual circles. With Place's help, Hodgskin launched a journalistic career by joining London's Morning Chronical as parliamentary reporter in 1822. It was from this perch as a political and economic journalist that Hodgskin made his principal contributions to political economy, both through his role in the Mechanics' Institute in London and, most significantly, through the three major treatises that he published between 1825 and 1832. In the following four chapters, which together form the core of his book, Mingardi investigates in detail the doctrines, arguments, and intellectual contexts of these three works. 
Labour Defended Against the Claims of Capital (1825) contains the core of Hodgskin's polemic against the capitalism of his time. Moreover, it is largely on account of its impassioned defense of economic reform that scholars have cast Hodgskin as a socialist. According to Mingardi, this portrayal is a deeply mistaken one that has long obscured Hodgskin's unique (and important) place in the history of political economy. Its error lies not in reading Hodgskin as an enemy of 'idle' capitalists and landlords but rather in inferring from that enmity a friendliness towards the kind of economic collectivism characteristic of socialism. By Hodgskin's lights, these economic villains are able to oppress the poor only insofar as the state intervenes on their behalf, as it inevitably does. If the state would simply refrain from meddling in economic matters, workers would enjoy the just fruits of their labor, and prosperity and liberty would overcome poverty and dependence. Hodgskin, as Mingardi reads him, is not so much opposed to capitalism per se as to crony capitalism in which the government props up the lazy and well-connected at the expense of the industrious common worker. If labor and the practical knowledge that powers it were permitted their proper rewards, there would be no need for any mechanism of distribution apart from the voluntary exchanges among worker-owners. Here, as Mingardi emphasizes, we begin to see the outsized influence of Adam Smith's economic thought on Hodgskin's doctrines.

The Smithian seed that took root in Labour Defended came to fruition in Hodgskin's Popular Political Economy (1827), to which Mingardi turns in his third chapter. Hodgskin's aim in this work, Mingardi explains, is to offer an account of political economy that is popular not in the sense of being watered-down or accessible but rather in the sense of being written "from the point of view of the people" rather than from the point of view of the crony-capitalist class (66). From this point of view, the fundamental question of political economy is distinctly Smithian: How can diffuse knowledge, including both theoretical understanding and know-how, guide an economic order towards prosperity and independence for the workers who possess and rely on that knowledge? In Hodgskin's political context, the fierce public debate over the protectionist Corn Laws, through which Parliament heavily taxed grain imports to maintain high grain prices for British landowners, constituted the backdrop against which this question, and others like it, arose. According to Hodgskin, the Corn Laws and similar acts of protectionism harm workers by "curb[ing] 
the spirit of enterprise, and imped[ing] production, by checking the progress of knowledge and the acquirement of skill" (79). For Hodgskin, as for Smith, there is an invisible hand at work in markets, a hand which, if permitted by the state to operate freely, will facilitate both the productive use of individual knowledge by laborers and the distribution of social knowledge through prices.

A similar Smithian spirit pervades Hodgskin's defense of free banking, to which Mingardi turns in chapter four. Parliament had begun in 1825 to increase the power and authority of the state-run Bank of England, partially in response to a banking crisis which had scuttled several large private banks that same year. Hodgskin argued that this policy "confers on [...] government a boundless power of working mischief" (105). This power is liable to cause inflation to a degree that would never occur if legislators would simply leave banking and banknotes, like all other facets of economic life, to private markets. Far from providing a way for the rich to ride high at the expense of the poor, private banking was, in Hodgskin's judgment, just one more dimension of the mutually beneficial market society that would emerge if only governors would let it. The state, in the sphere of banking as in other spheres, can only make things worse.

Although the Smithian strain in Hodgskin's economic thought is very pronounced, it coexists with a distinct, though not unrelated, Lockean strain. Mingardi details in chapter five how this dimension of Hodgskin's thinking is foundational to his account of property rights and their natural (as opposed to political) character. In The Natural and Artificial Right of Property Contrasted (1832), Hodgskin argues, following John Locke, that workers enjoy natural property rights in whatever they produce through their labor. This is because each person owns herself, and labor extends the self to encompass what her labor produces. Indeed, the conceptual relationship that Hodgskin posits between personal identity and natural property rights is so tight that to doubt the reality and absolute strength of those rights is to be irrational or even "insane" (Hodgskin 1832, 30). Property theory is therefore a kind of demonstrative natural science that has nothing at all to do with politics. Indeed, by Hodgskin's lights, any attempts by governments to pass positive law defining property rights-attempts of the kind endorsed by Jeremy Bentham, the archvillain of Natural and Artificial - can be nothing less than irrational and anti-scientific usurpations of natural right: there is, and can be, no artificial right of property at all. 
Having considered in detail all three of Hodgskin's primary works, Mingardi concludes with some reflections on Hodgskin's influence. He suggests that, despite Herbert Spencer's claims to the contrary, there is reason to suppose that Hodgskin influenced Spencer, whom he knew personally in the context of his career as a journalist. In particular, Mingardi hears echoes of Hodgskin's voice in Spencer's critique of statism, which, like Hodgskin's own critique, turns on the idea of economic complexity. This idea would, moreover, come to define Hayek's economic outlook nearly a century later. It is in virtue of these relationships that Hodgskin occupies an important place in the development of classical liberalism as we know it today.

Mingardi's book offers the most complete and coherent reconstruction of Hodgskin as a systematic figure so far. Moreover, the book retires-hopefully once and for all-the lazy assumption that since Hodgskin supported working-class causes and opposed the capital structure of his time and place, he must have been a socialist. As Mingardi makes clear, Hodgskin sought not to replace concentrated aristocratic control of property with concentrated democratic control, but rather, to liberate economic life from centralized control of any kind. Far from offering some kind of proto-Marxism, Mingardi's Hodgskin channels the legacies of Smith and Locke into a radical form of anti-statist classical liberalism. Mingardi pierces the interpretive fog of assumed socialism that has crept up around Hodgskin over the decades; consequently, his book merits wide attention, close study, and vigorous engagement.

In the remainder, I'd like to draw out and reflect on a tension between the Lockean and Smithian dimensions of Hodgskin's thought to which Mingardi draws attention. In a Lockean voice, Hodgskin claims that natural property rights form an eternal, complete, and rationally accessible system-that is, a moral science. Property rights are thus radically prepolitical, and there is neither need nor license for legislatures to alter them. But in his more Smithian (and proto-Hayekian) passages, Hodgskin argues that economic relationships emerge from and constitute a spontaneous order that individual minds cannot possibly comprehend. Both of these lines of thought support Hodgskin's anti-statist-and, in particular, anti-legislative-position, but they do so on different and seemingly incompatible grounds. From the Lockean perspective, there is no legitimate legislative task with respect to property rights, because any minimally rational individual can grasp and respect them. But from the Smithian perspective, there is no need for legislatures to meddle in economic matters 
because spontaneous order settles all economic questions conclusively and to the benefit of all. Despite rendering similar policy prescriptions, it is not immediately clear how these two approaches can accommodate one another.

Mingardi's text suggests a solution rooted in Hodgskin's conception of human life as governed by natural laws. Just as legislators ignore the natural law of individual motivation and action when they fail to recognize the roots of property in the self-owned individual and her labor, they ignore the natural law of human exchange when they attempt to regulate markets or, as they are especially wont to do, give special privileges to particular market actors. The natural law of property creation and the natural law of exchange, however, are not nomological isolates; to the contrary, they constitute, respectively, the micro-level and macro-level dimensions of one and the same comprehensive natural law of human behavior. From the birth of property at laborers' hands to the most complex (private) banking transactions, all economic behavior follows from and expresses the same rational and determinate law.

Although Hodgskin's endorsement of this comprehensive law-governed economic-cum-social science may reconcile his Lockean and Smithian commitments, it raises two problems. First, it seems to commit Hodgskin to a kind of determinism about human action that is nowhere present in either Locke or Smith and which threatens human freedom and responsibility. Second, insofar as Hodgskin attempts to derive his political conclusions from what naturally does happen in human life, he threatens to crowd out the normativity necessary for the judgments about what should happen in human life on which those conclusions depend. I very much hope that scholars will take up these problems in Hodgskin, and that they will rely on Mingardi's fine book as they do so.

\section{REFERENCES}

Berlin, Isaiah. 2019. "Socialism and Socialist Theories." In The Sense of Reality: Studies in Ideas and their History, edited by Henry Hardy, 96-145. Princeton, NJ: Princeton University Press.

Hodgskin, Thomas. 1832. The Natural and Artificial Right of Property Contrasted. London: B. Steil.

Layman, Daniel. 2020. Locke Among the Radicals: Liberty and Property in the Nineteenth Century. New York, NY: Oxford University Press.

Stack, David. 1998. Nature and Artifice: The Life and Thought of Thomas Hodgskin (1787-1869). Rochester, NY: Boydell and Brewer. 
Daniel Layman is Assistant Professor of Philosophy at Davidson College. He is the author of Locke Among the Radicals: Liberty and Property in the Nineteenth Century (New York, NY: Oxford University Press, 2020) and the co-author (with Michael Huemer) of Do Governments Have Moral Authority? A Debate (New York, NY: Routledge, forthcoming).

Contact e-mail: <dalayman@davidson.edu> 